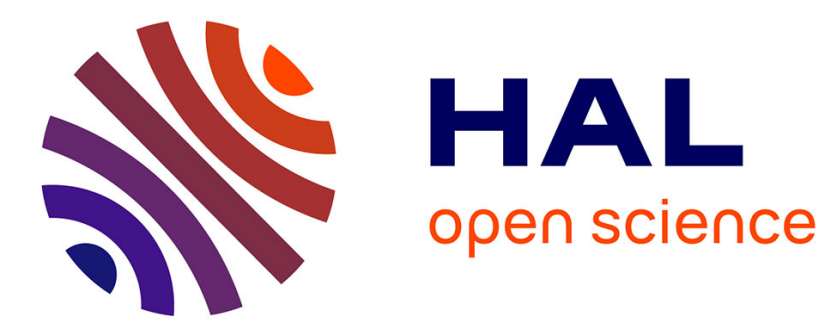

\title{
Comparison of aerobic processes for olive mill wastewater treatment
}

Y. Jaouad, M. Villain-Gambier, L. Mandi, B. Marrot, N. Ouazzani

\section{To cite this version:}

Y. Jaouad, M. Villain-Gambier, L. Mandi, B. Marrot, N. Ouazzani. Comparison of aerobic processes for olive mill wastewater treatment. Water Science and Technology, 2020, 81 (9), pp.1914-1926. 10.2166/wst.2020.247 . hal-03232154

\section{HAL Id: hal-03232154 https://hal.science/hal-03232154}

Submitted on 25 May 2021

HAL is a multi-disciplinary open access archive for the deposit and dissemination of scientific research documents, whether they are published or not. The documents may come from teaching and research institutions in France or abroad, or from public or private research centers.
L'archive ouverte pluridisciplinaire HAL, est destinée au dépôt et à la diffusion de documents scientifiques de niveau recherche, publiés ou non, émanant des établissements d'enseignement et de recherche français ou étrangers, des laboratoires publics ou privés. 


\title{
Comparison of aerobic processes for olive mill wastewater treatment
}

\author{
Y. Jaouad, M. Villain-Gambier, L. Mandi, B. Marrot
}

and N. Ouazzani

\begin{abstract}
$\overline{\text { ABSTRACT }}$
Membrane bioreactor (MBR) has been proven to be an efficient technology capable of treating various industrial effluents. However, the evaluation of its performances in the case of olive mill wastewater (OMW) over a conventional activated sludge (CAS) have not been determined yet. The present study aims to compare OMW treatment in two laboratory scale pilots: an external ceramic MBR and CAS starting with an acclimation step in both reactors by raising OMW concentration progressively. After the acclimation step, the reactors received OMW at $2 \mathrm{gcoD} / \mathrm{L}$ with respect to an organic loading rate of 0.2 and $0.3 \mathrm{~kg}$ COD $/ \mathrm{kg}_{\mathrm{MLvsS}} / \mathrm{d}$ for MBR and CAS, respectively. Biomass acclimation occurred successfully in both systems; however, the MBR tolerated more OMW toxicity than CAS as the MBR always maintained an effluent with a better quality. At a stable state, a higher reduction of $95 \%$ chemical oxygen demand (COD) was obtained with MBR compared to CAS (86\%), but both succeeded in polyphenols removal (80\%). Moreover, a higher MLSS elimination from the MBR treated water (97\%) was measured against $88 \%$ for CAS. Therefore, CAS was suitable for OMW treatment and MBR could be proposed as an alternative to CAS when a better quality of treated water is required.

Key words | acclimation, aerobic treatment, COD and phenolic compounds removal, conventional activated sludge process, external ceramic membrane bioreactor, olive mill wastewater

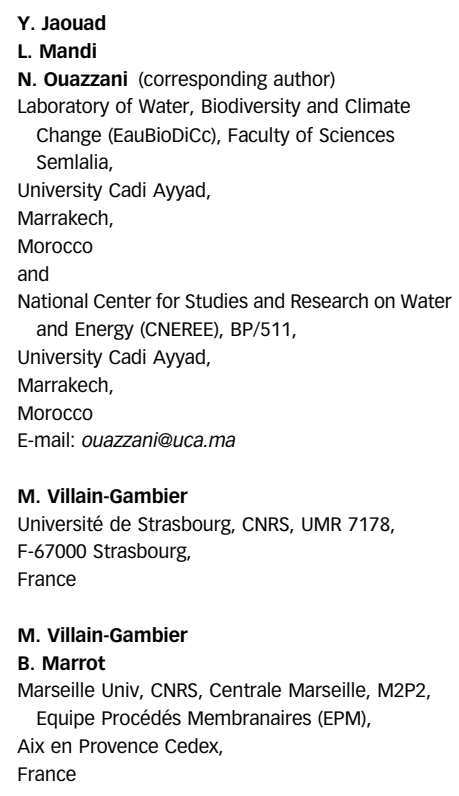

\section{HIGHLIGHTS}

- Olive mill wastewater (OMW) treatment by membrane bioreactor (MBR) and activated sludge (AS) were compared.

- Biomass acclimation and polyphenols degradation occurred successfully in both systems.

- At 0.2 and $0.3 \mathrm{kgCOD} / \mathrm{kgMLVSS} / \mathrm{d}$, MBR showed higher efficiency at $95 \%$ than CAS (86\%).

- MBR showed better performances (95\%) than CAS (86\%) for OMW COD treatment.

- Considering the Moroccan situation, the CAS could be more adapted for OMW treatment.

\section{INTRODUCTION}

Olive oil production is one of the main agro-industries in Mediterranean countries and the production of olive oil is increasing due to the nutritional benefits and economic interest of this substance. However, the activity generates significant amounts of olive mill wastewater (OMW), which represents a serious environmental problem in many producing countries. The OMW volume produced during the process varied from 40 to $60 \mathrm{~L}$ for pressing method and it ranged from 100 to $120 \mathrm{~L}$ for triple phase centrifugation method per $100 \mathrm{~kg}$ of olives (Rahmani 20IO). The OMW is one of the most contaminant effluent for the environment. The 5-day biochemical oxygen demand 
(BOD5) values are between 12 and $63 \mathrm{~g} / \mathrm{L}$ and chemical oxygen demand (COD) values are between 80 and $200 \mathrm{~g} / \mathrm{L}$. These concentrations are around 200-400 times higher than those measured in typical municipal sewage. In addition, OMW contains phenolic compounds which are recognized with phytotoxic and antimicrobial properties.

Several methods are being used for the treatment of OMW such as electrochemical oxidation, stabilization ponds, thermal concentration, and other physicochemical treatments (Paraskeva \& Diamadopoulos 2006). However, most methods are expensive and produce sludge and other secondary by-products which need to be further treated. The aerobic methods are recognized as economic alternatives to physicochemical methods for the treatment of a wide range of wastewater effluents. In most cases, conventional activated sludge (CAS) is used and preferred for large-scale application (Sipma et al. 20Io). However, the feeding of this system by highly toxic OMW could be harmful and disturbing for its normal functioning. The inhibition of the biodegradation might occur because of the proper toxicity of OMW phenolic compounds towards microorganisms (Esmail et al. 20I5).

The membrane bioreactor (MBR) has attracted attention concerning its high ability for the removal of a large type of contaminants including phenolic compounds (Baresel et al. 20I9). The integrated membrane in the MBR replaces the clarifier in CAS process with settling ability problems. The MBR treatment of industrial wastewater has become attractive for the robustness of the process to treat high organic load and inhibitory compounds (Fazal et al. 20I5). The main problem associated with MBR process is membrane fouling, therefore, it has to be managed in order to guarantee the development of a sustainable process. Soluble microbial products (SMP) are currently considered as the main part of extra polymeric substances (EPS) which are responsible for membrane fouling. Due to the lack of information about the characteristics of SMP in MBR and CAS treating OMW, one of the main objectives of this study is to assess the feature and appearance of SMP in both reactors and to link their production to the operating conditions. The treatment of OMW in MBR was successfully performed in previous studies with a preliminary acclimation step. The COD and phenolic compounds removals in the range of 80-95\% and 80-90\% were respectively reached (Dhaouadi \& Marrot 2008; Jaouad et al. 20I8). As the effluent treatment with MBR was reported to be more expensive than CAS treatment (Bertanza et al. 2017), the objective of the current study is to investigate and compare the performances of two pilots, MBR and CAS, operating simultaneously for the treatment of OMW. The COD and phenolic compounds removal efficiencies and the quality of the treated water were principally assessed during the running of both pilots. A strategy of OMW treatment in Morocco was then proposed. The purpose of this strategy is to demonstrate which one of the reactors is effective in OMW wastewater treatment considering the Moroccan context.

\section{$\overline{\text { MATERIALS AND METHODS }}$}

\section{MBR and CAS pilots set up}

A laboratory scale MBR system (30 L) (Polymem, France) was used in this study. The membrane was placed outside of the bioreactor and operated under a cross flow velocity of $4 \mathrm{~m} / \mathrm{s}$ to reduce membrane blockage. Diagrams of the pilot plants are presented in Figure 1.

The aerobic tank was supplied by $30 \mathrm{~L}$ activated sludge and the aeration was provided by small bubble diffusers $\left(6-8 \mathrm{mgO}_{2} / \mathrm{L}\right)$. Recirculation of activated sludge from the aeration tank to the membrane was accomplished by recirculation pump. The temperature was maintained at $25^{\circ} \mathrm{C}$ (a)
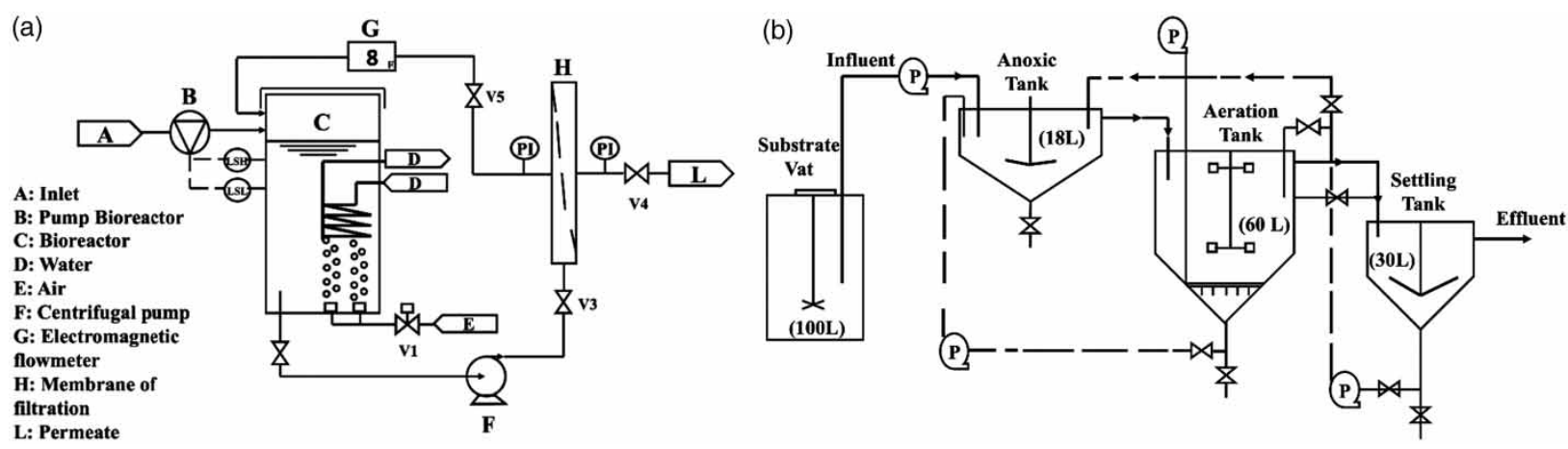

Figure 1 | Schematic diagram of MBR (a) and CAS (b) installations. 
inside the bioreactor using a cooling coil system. Initially, the experiment was conducted by an ultrafiltration (UF) membrane to retain specific enzymes involved in phenolic compounds removal. Afterwards, the UF membrane was replaced by a microfiltration (MF) membrane to guarantee a constant flow rate of the permeate with less membrane fouling. Both of the used membranes (UF and MF) were tubular mono-channel ceramic types (Novasep-Orelis, France) with an effective filtration area of $0.02 \mathrm{~m}^{2}$, initial water permeability of $100 \mathrm{~L} / \mathrm{h} / \mathrm{m}^{2} / \mathrm{bar}$. The pore size of UF membrane was $150 \mathrm{kDa}$ while it was $0.1 \mu \mathrm{m}$ for the MF membrane. Transmembrane pressure (TMP) increase was controlled with two manometers set at the inlet and outlet of membrane module (alimentation and retentate). Both permeate and feed flows were kept constant at $0.75 \mathrm{~L} / \mathrm{h}$.

The second reactor was a pilot-scale automated activated sludge plant (TAE/3000) (Figure 1(b)). The pilot is composed of three tanks: feed wastewater tank $(100 \mathrm{~L})$, aerobic tank with a working volume of $60 \mathrm{~L}$ and containing flocculated activated sludge. The settling tank $(30 \mathrm{~L})$ is the final module where the flocculated activated sludge is separated from the treated water. A part of sludge in the settling tank was regularly recirculated into the bioreactor to ensure the presence of a significant biomass amount inside the biological reactor. Ambient temperature was maintained at approximately $25^{\circ} \mathrm{C}$. In the aeration tank, the oxygen was provided by an air pump and diffused inside the bioreactor using a large diffuser at a concentration of $2-3 \mathrm{mgO}_{2} / \mathrm{L}$.

\section{Operating conditions}

Initially, the pilots were filled with activated sludge. In the case of MBR, the activated sludge was supplied from a submerged MBR treating municipal wastewater of the village Le Rousset (France, 12,000 inhabitants equivalent, $1,800 \mathrm{~m}^{3} / \mathrm{d}$ flow rate, organic load $0.1 \mathrm{~kg}_{\mathrm{BOD} 5} / \mathrm{kg}_{\mathrm{MLVSS}} / \mathrm{d}$ ). For the CAS plant, the biomass was taken from a full-scale municipal wastewater treatment (WWTP-AS) of Marrakesh (Morocco, 1,300,000 inhabitants equivalent, 120,000 m³ $/ \mathrm{d}$ flow rate). Initial mixed liquor suspended solids (MLSS) concentrations were around $4 \mathrm{~g}_{\mathrm{MLSS} / \mathrm{L}}$ for CAS and $8 \mathrm{~g}_{\text {MLSS }} / \mathrm{L}$ for MBR process. Then, the biomass was preadapted in both pilots to a synthetic substrate containing glucose as carbon source: $\mathrm{C}_{6} \mathrm{H}_{12} \mathrm{O}_{6} \quad\left(2.1 \mathrm{~g} / \mathrm{g}_{\mathrm{MLVss}}\right)$, $\mathrm{KH}_{2} \mathrm{PO}_{4}\left(0.2 \mathrm{~g} / \mathrm{g}_{\mathrm{MLVss}}\right), \mathrm{NaHCO}_{3}\left(0.3 \mathrm{~g} / \mathrm{g}_{\mathrm{MLVSs}}\right), \mathrm{MgSO}_{4}$ $\left(0.1 \mathrm{~g} / \mathrm{g}_{\mathrm{MLVSS}}\right)$ and $\mathrm{CaCl}_{2}\left(0.02 \mathrm{~g} / \mathrm{g}_{\mathrm{MLVss}}\right)$. Afterwards, the biomass was acclimated to gradual concentrations of OMW following the acclimation procedure described by Jaouad et al. (20I6). During the acclimation step, the food to microorganism ratio $(\mathrm{F} / \mathrm{M})$ was kept around $0.3 \mathrm{~kg}_{\mathrm{COD}}$ / $\mathrm{kg}_{\text {MLVSs }} / \mathrm{d}$ with a starting ratio of $20 \%$ OMW/ $80 \%$ glucose $(\mathrm{v} / \mathrm{v})$. Then the volume of OMW increased progressively as the biomass growth was noticed for several days.

Based on the finding from Jaouad et al. (2016), the maximum biomass growth $(1.8 / \mathrm{d})$ can be obtained with OMW using a COD concentration of $2 \mathrm{~g}_{\mathrm{COD}} / \mathrm{L}$ and tended to decline after further augmentation of OMW concentration (superior to $2 \mathrm{~g}_{\mathrm{COD}} / \mathrm{L}$ ). Therefore, at the end of the acclimation step, the dilution of the raw OMW effluent until $2 \mathrm{~g}_{\mathrm{COD}} / \mathrm{L}$ was necessary to avoid substrate inhibition effect. The acclimation phase was performed under an infinite sludge retention time (SRT) for both reactors and different hydraulic retention time (HRT) of $16 \mathrm{~h}$ for AS and $24 \mathrm{~h}$ for MBR. At steady state, for the microfiltration step (MF-MBR), the F/M ratio and the mixed liquor volatile suspended solid (MLVSS) were fixed at $0.2 \mathrm{~kg}$ COD $/ \mathrm{kg}_{\mathrm{MLVSS}} / \mathrm{d}$ and $8 \mathrm{~g} / \mathrm{L}$, respectively. The MBR alimentation was done continuously with a constant OMW loading, previously pre-filtered (cut off of $200 \mu \mathrm{m}$ ). In addition, a daily purge was performed in order to keep a constant value of MLVSS concentration of $8 \mathrm{~g} / \mathrm{L}$ in the MBR and to minimize membrane fouling. For the CAS pilot, the bioreactor was fed only by OMW at a fixed F/M ratio of $0.3 \mathrm{~kg}$ COD $/ \mathrm{kg}_{\text {MLVss }} / \mathrm{d}$. In addition, a frequent purge was performed to maintain 4 to $5 \mathrm{~g}_{\mathrm{MLVSS}} / \mathrm{L}$ in the CAS bioreactor and to ensure a high water clarification. The stabilization of the system was obtained a few days later. The SRT were fixed at 20-25 days for both pilots.

The OMWs used in this experience were sampled at two different periods (in 2013 for OMW1 and in 2014 for OMW2) from a discontinuous extraction unit from Marrakesh, southern Morocco (Table 1). To obtain comparable results, the alimentation of the two pilot plants by OMWs was performed using similar F/M ratio of $0.3 \mathrm{~kg} \mathrm{COD} / \mathrm{kg}_{\mathrm{MLVss}} / \mathrm{d}$.

\begin{tabular}{|c|c|c|}
\hline Parameters & OMW1 (MBR) & OMW2 (CAS) \\
\hline $\mathrm{pH}\left(25^{\circ} \mathrm{C}\right)$ & 5 & 4.1 \\
\hline Conductivity (mS/cm) & 9.3 & 16 \\
\hline Total suspended solids (TSS) (g/L) & $2.1 \pm 0.3$ & $4.5 \pm 0.2$ \\
\hline $\operatorname{COD}(\mathrm{g} / \mathrm{L})$ & $96 \pm 2$ & $170 \pm 5$ \\
\hline Total nitrogen $(\mathrm{TN})(\mathrm{g} / \mathrm{L})$ & 0.46 & $2.6 \pm 0.1$ \\
\hline Total phosphorus (TP) (g/L) & $0.1 \pm 0.03$ & $0.3 \pm 0.02$ \\
\hline Total polyphenols (g/L) & $3.2 \pm 0.01$ & $8.1 \pm 0.4$ \\
\hline Proteins (g/L) & 0.04 & 0.004 \\
\hline
\end{tabular}




\section{Analytical methods}

For both pilots, samples were taken from the influent, bioreactor and the outlet to perform various analysis. Activated sludge was taken from the aeration reactor and centrifuged at $4,000 \mathrm{~g}$ for $15 \mathrm{~min}$ to separate suspended solids from the supernatant; the measure of mixed liquor suspended solids (MLSS) was obtained by drying solid residues in a stove at $105^{\circ} \mathrm{C}$ for $24 \mathrm{~h}$. The MLVSS content was determined by placing the dried solid residues in an oven at $550{ }^{\circ} \mathrm{C}$ for $2 \mathrm{~h}$. These MLSS and MLVSS were measured daily to evaluate the biomass growth in both systems. The COD and phenolic compounds content was assessed twice a week by colorimetric methods to assess their removal rates. The TMP was measured to monitor the filtration performances and membrane fouling. Once the TMP reached high values ( $>1.2$ to 1.5$)$, a chemical cleaning of the membrane was applied to restore initial values of TMP and a constant permeate flow of $0.75 \mathrm{~L} / \mathrm{h}$. In addition, the total MLSS in the outlet of both pilots was determined to evaluate the quality of the final water obtained over the treatments. The monitoring of sludge volume index (SVI) was performed periodically to evaluate the quality of sludge settleability over time. The polysaccharide fraction of SMP was determined by the phenol sulfuric acid method, as described by Dubois et al. (1956). Moreover, the method developed by Frolund et al. (1995) was applied to determine the proteins and humic fractions of SMP content.

\section{RESULTS AND DISCUSSION}

\section{Evolution of the biomass}

The evolution of MLSS, MLVSS and F/M ratio during the operation of MBR and CAS pilots is given in Figure 2.

This figure illustrates an increase in the biomass content gradually with the rise of OMW concentration with time, proving that the acclimation step was successfully performed in both reactors. In the MBR, the MLVSS content increased and reached the high concentration of $10 \mathrm{~g} / \mathrm{L}$ at a ratio of $40 \%$ OMW $/ 60 \%$ glucose. The $150 \mathrm{kDa}$ UF was used in the initial acclimation step to retain enzymes involved in phenolic compounds removal. However, with the increase of OMW ratio to $60 \%$ OMW $/ 40 \%$ glucose (day 51), a brutal decrease of MLVSS concentration occurred. At the same time, the MLSS concentration stayed around $10 \mathrm{~g} / \mathrm{L}$. It seems that the biomass is under remarkably high toxicity conditions. This could be related to an effective presence of highly toxic phenolic compounds inside the bioreactor which was set up by the small size of the pore $(150 \mathrm{kDa} U \mathrm{UF})$. A rearrangement of organic matter from OMW, in particular phenolic compounds with bacterial flocs and SMP could be responsible for the rapid increase of biomass instability and death. Then, the UF was replaced by an MF membrane in order to limit the toxic OMW molecules' accumulation inside the MBR. Similar to the MBR, the MLVSS content in CAS increased in parallel with the injection of new doses of OMW, which shows a good biomass adaptation to this toxic effluent. The MLVSS content for CAS pilot reached a concentration of $4.3 \mathrm{~g} / \mathrm{L}$ at $90 \%$ of OMW as mass ratio. After the increase of OMW concentration in CAS to $100 \%$ at day 55 , the biomass content remained high and stable, showing the adaptation of biomass to this harsh environment. Concerning the MBR, with the change of UF by an MF and despite feeding the bioreactor by OMW only, the biomass continued to increase to reach $20 \mathrm{~g}_{\mathrm{MLVSS}} / \mathrm{L}$.

The steady state was reached at day 110 for MBR at an F/M ratio of $0.2 \mathrm{~kg}_{\mathrm{COD}} / \mathrm{kg}_{\mathrm{MLVSS}} / \mathrm{d}$ and MLVSS of $8 \mathrm{~g}_{\mathrm{MLVSS}} / \mathrm{L}$ while for the CAS the system stabilization was obtained at day 55 at a fixed MLVSS of $5 \mathrm{~g}_{\mathrm{MLVSS}} / \mathrm{L}$ and a F/M ratio of $0.3 \mathrm{~kg}_{\mathrm{COD}} / \mathrm{kg}_{\mathrm{MLVSS}} / \mathrm{d}$.

\section{Treatment performances}

COD removal. Figure 3 represents the performance of MBR and CAS reactors for the COD removal during time. During the first step of acclimation, until a ratio of $40 \%$ OMW, the MBR showed a higher elimination of COD (95\%) than CAS (86\%).

Afterwards, with the increase of OMW mass ratio to $60 \%$ in the MBR, an accumulation of COD in the bioreactor was observed throughout the experiment. However, the MBR kept a high COD removal (95\%) and a good permeate quality. This result could be explained by the presence of a membrane that retained the pollutants and kept the water free of them even if biological fluctuation occurred. However, in the case of CAS, the increase of OMW mass ratio (between $40 \%$ and 90\%) involved highly stressful conditions inside the bioreactor reflected by a slight decrease of COD removal to $80 \%$. The harsh atmosphere inside the bioreactor affected the biomass biodegradation efficiency and the clarification efficiency as well. However, at day 55 the COD removal efficiency reached again an optimal value of $86 \%$ at the same time of the biomass adaptation. It appeared from these results that the MBR has more abilities to produce constantly a highly treated water than CAS and 

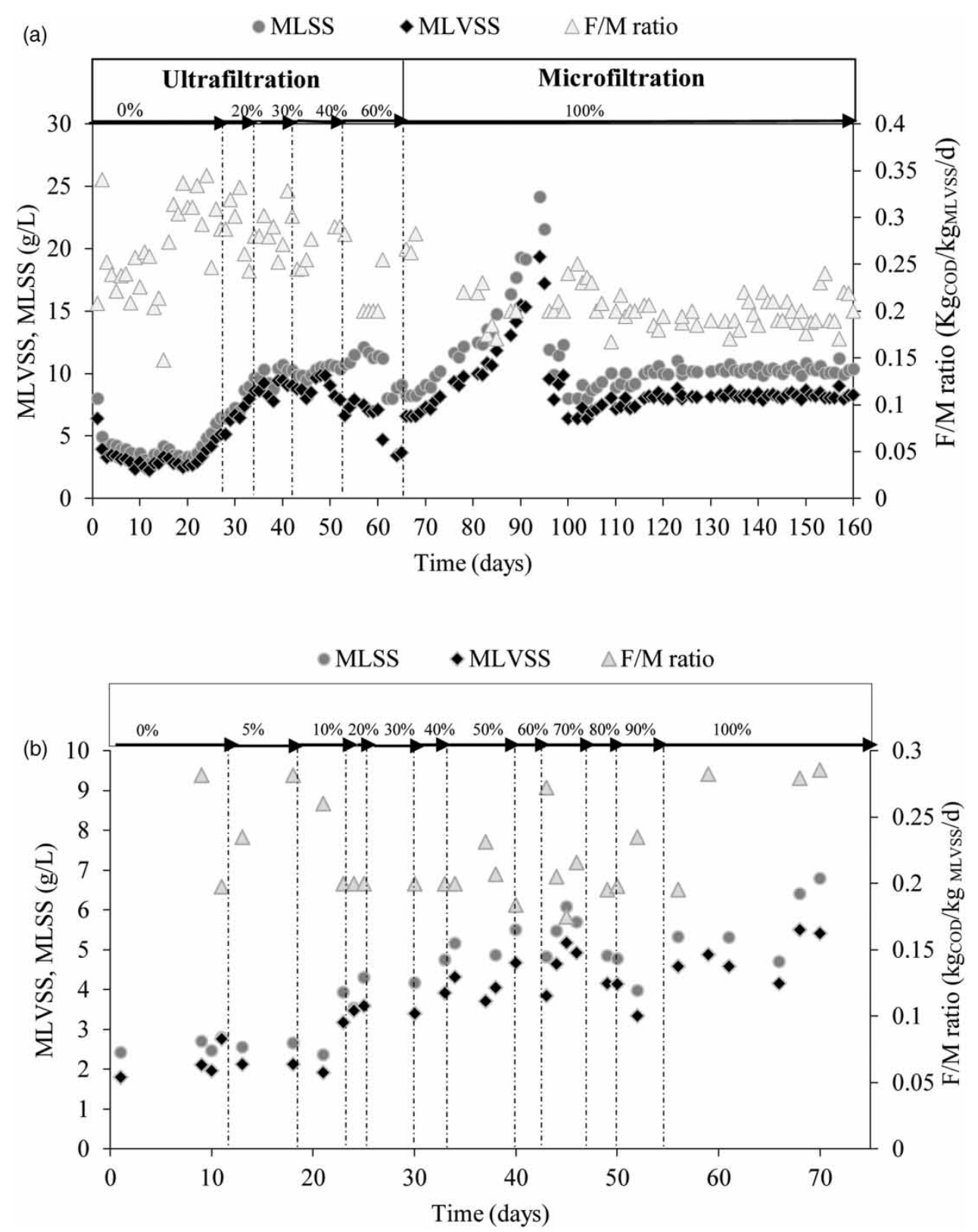

Figure 2 | Evolution of MLVSS, MLSS and F/M ratio during time for MBR (a) and CAS (b).

limits biological disturbance inside the bioreactor. The UF was then replaced by an MF membrane. That way, the bioreactor allowed to eliminate compounds with sizes ranging between $150 \mathrm{kDa}$ and $0.1 \mu \mathrm{m}$ that accumulated.

After the application of MF, at the stable state, the biomass showed high activity towards OMW pollutants removal. The MBR performance was noticeable and the removal of COD reached the high value of $95 \%$ while it not exceeded $86 \%$ for CAS. Furthermore, the MBR delivered an effluent with lower COD concentration $(0.107 \mathrm{~g} / \mathrm{L})$ than
CAS $(0.152 \mathrm{~g} / \mathrm{L})$ which complies largely with the limits fixed by the Moroccan Standards for Wastewater Discharge $(0.120 \mathrm{~g} / \mathrm{L})$ (Moroccan Standards for Wastewater Discharge 20I3). The MBR was able to achieve a higher elimination of COD compared to CAS. The greater elimination of organics by the MBR was due to the presence of a MF membrane, which worked in synergy with the biomass for a better biodegradation of OMW.

The performance of CAS and MBR in this study for the treatment of OMW was compared to the efficiencies of 
(a) OSubstrate OSupernatant $\bullet$ Permeate $\quad$ COD removal

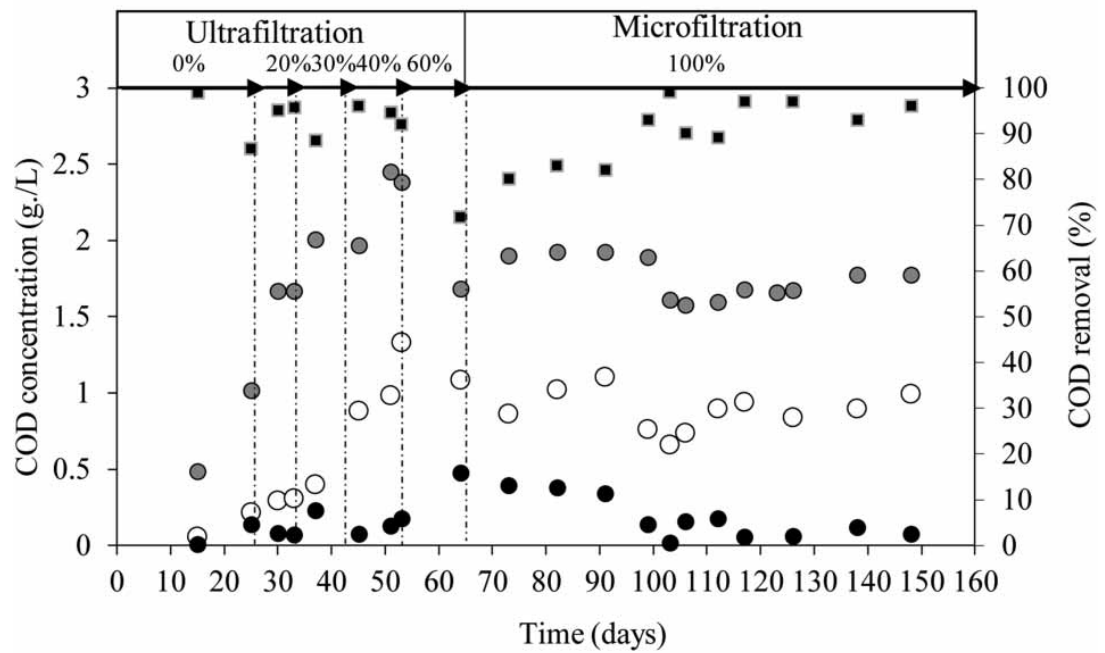

(b) - Substrate O supernatant $\bullet$ settling tank $\bullet$ COD removal

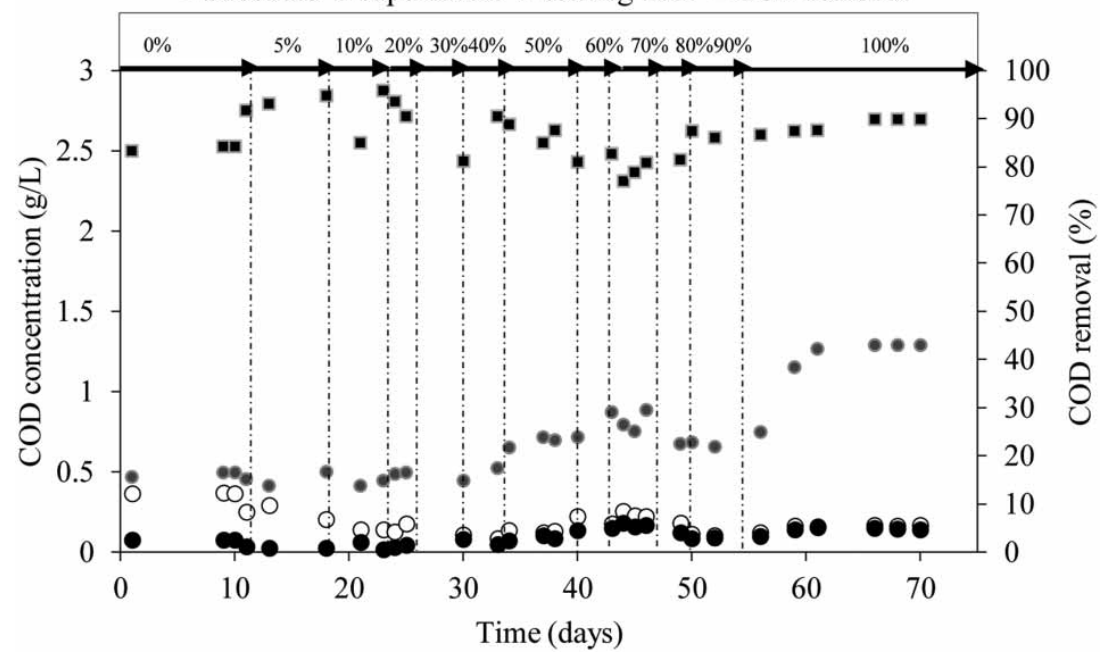

Figure 3 | COD removal and COD concentrations in substrate, MBR supernatant and permeate as a function of time for MBR (a) and CAS (b).

Table 2 | COD and phenol removals for OMW treatment with different processes

\begin{tabular}{|c|c|c|c|c|c|}
\hline Process & Type of treatment (single or combined) & $\begin{array}{l}\text { COD inlet } \\
(g / L)\end{array}$ & $\begin{array}{l}\text { COD removal } \\
\text { (\%) }\end{array}$ & $\begin{array}{l}\text { Phenol removal } \\
\text { (\%) }\end{array}$ & Reference \\
\hline AS & Single & 1.1 & 86 & 82 & This study \\
\hline MBR & Combined (AS/microfiltration) & 1.6 & 95 & 80 & \\
\hline Photocatalytic & $\begin{array}{l}\text { Combined (Anaerobic fermentation/ } \\
\mathrm{TiO}_{2}-\mathrm{PAC} \text { ) }\end{array}$ & 1.9 & 58 & - & Baransi et al. (2012) \\
\hline Electrocoagulation & Combined (UF/EC) & 1.1 & 78 & - & Yahiaoui et al. (20II) \\
\hline AS & Combined (UASB/AS) & 0.6 & 60 & - & Gizgis et al. (2006) \\
\hline UASB & Single & 2.8 & 93 & - & Ergüder et al. (2000) \\
\hline SBR & Combined (GAC/SBR) & 1.3 & 40 & - & Farabegoli et al. (20I2) \\
\hline Biofilters & Combined (UF/NF/RO/Biofiltration) & 1.2 & 63 & - & Stoller et al. (2016) \\
\hline
\end{tabular}


other advanced technologies. As noticed in Table 2, MBR appears to achieve the highest COD removal (95\%) compared to the last stages of the other combined treatment processes (Anaerobic fermentation/TiO2-PAC; UF/EC; UASB/AS; GAC/ SBR; UF/NF/RO/Biofiltration). The presence of MF membrane acted as a solid physical barrier for better wastewater impurities retention and therefore obtaining a better treated water compared to the other combined processes. Even if the CAS performance to treat OMW $(86 \%)$ was much lower than MBR, it obviously showed from Table 2 that the process achieved higher COD elimination compared to the two other studies using the aerobic biodegradation as a last stage in the combined treatment (UASB/AS; GAC/SBR). The higher COD removal rate could be attributed to the acclimation protocol performed in this study which allowed the best treatment profile for CAS.
Polyphenol removal. The performance of MBR and CAS for the removal of phenolic compounds during the operation time is presented in Figure 4. During the acclimation step, at low OMW concentrations (20-40\% mass ratio) feeding the bioreactor, the MBR showed an acceptable elimination of phenolic compounds (65\%) against 54\% for CAS.

This result could be explained by the fact that in the MBR the biomass content was greater $(8 \mathrm{~g} / \mathrm{L})$ than in CAS $(4 \mathrm{~g} / \mathrm{L})$. At the same time, the MBR biomass was constituted of flocs with a smaller size $(35 \mu \mathrm{m})$ than CAS $(150 \mu \mathrm{m})$. This implied that with the decrease of flocs size, the flocs exchange surface has increased in the case of MBR and the adsorption of the phenolics compounds has increased as well. When OMW mass ratio increased to $60 \%$, an accumulation of phenolic compounds was noticed which seems caused by the very low fine pore size of UF membrane
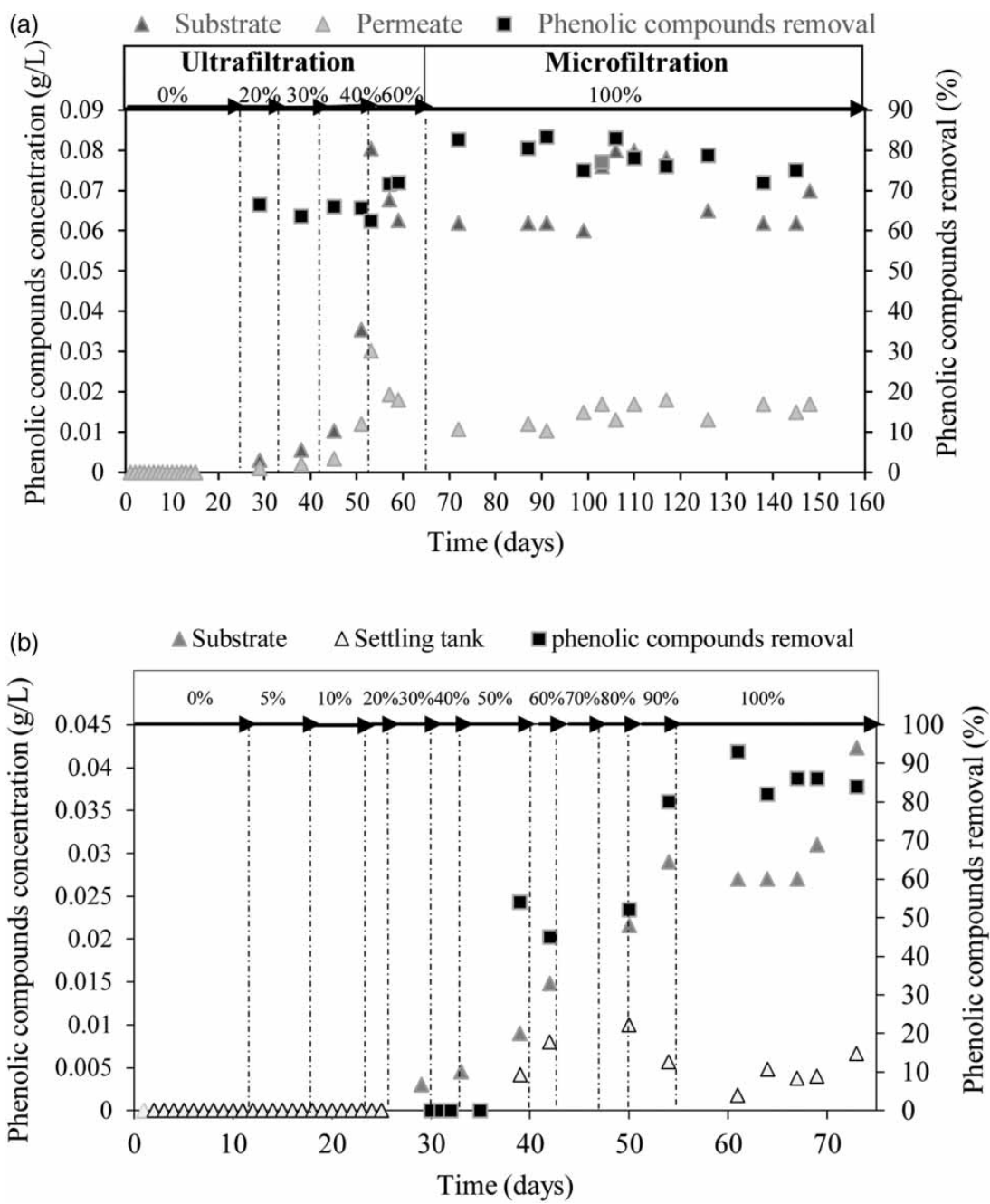

Figure 4 | Phenolic compounds removal and phenolic compounds concentrations in substrate and permeate as a function of time for MBR (a) and CAS (b). 
$(150 \mathrm{kDa})$. However, the removal of phenolic compounds remained acceptable at 65\%. The UF membrane was then replaced by an MF membrane in order to get rid of the phenolic compounds accumulated inside the bioreactor. For CAS, the phenolic compounds removal improved during the operation time from $54 \%$ to $80 \%$. This result shows the gradual adaptation of the biomass to OMW toxicity during the acclimation period leading to an effective elimination of these compounds in the CAS bioreactor. During the last period of acclimation, both reactors were fed totally with OMW. At stable state, the elimination of phenolic compounds was fixed at around $80 \%$ for both reactors.

Hydraulic performances. Figure 5 illustrates the evolution of SVI for CAS treatment and TMP as well as permeate flux during the functioning of MBR. The monitoring of these parameters was in order to compare the performance and the extent to which these two plants can produce a treated water with a high quality together with the influence of hydrodynamic conditions fixed over both experiments on flocs decantability in CAS or on membrane fouling in MBR.

In the case of MBR, during the acclimation period the TMP has known a frequent increase simultaneously with the introduction of OMW in a new higher concentration leading to significant membrane fouling occurrence over time. On the other side, the quality of water clarification remained good as confirmed by the high COD removal efficiency obtained (95\%). As can be seen, the low cut off of UF membrane was appropriate to obtain an effluent with a high quality; however, this membrane seems to be responsible for the rapid, easy and frequent membrane fouling appearance. The UF has influenced indirectly the accumulation of molecules with high molecular weight in the bioreactor supernatant over the progressive introduction of OMW in a new higher concentration and, hence, their contribution on membrane fouling. Furthermore, the very low pore size of UF has permitted a rearrangement between sludge flocs,

(a) $\bullet$ TMP $\quad$ Permeate flux
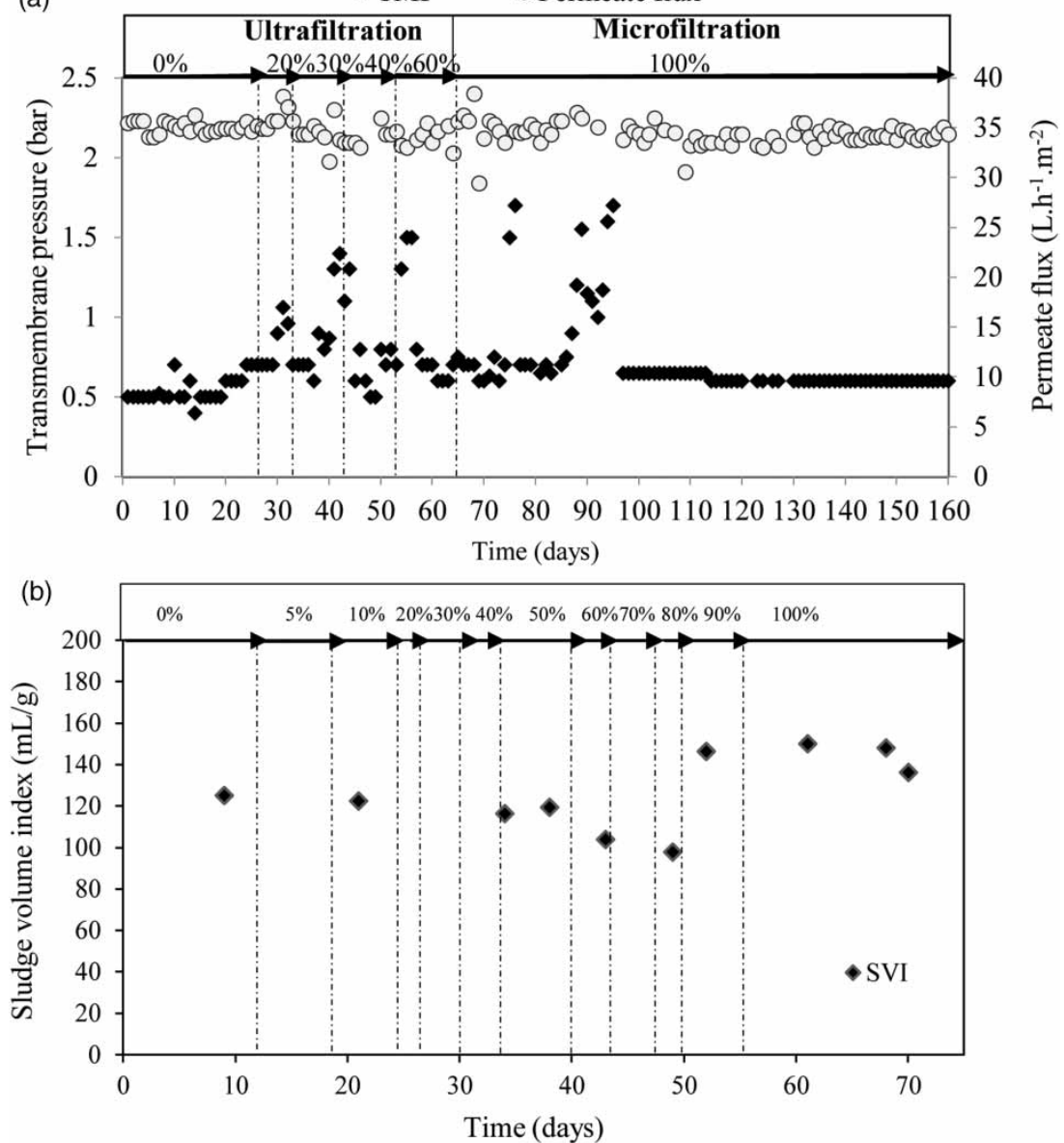

Figure 5 | Evolution of TMP for MBR (a) and SVI for CAS (b). 
SMP and OMW compounds, which participated greatly in membrane fouling. Then, the UF was replaced by an MF membrane $(0.1 \mu \mathrm{m})$.

The monitoring of SVI parameter was performed during the operation time of CAS since it gives a direct measurement of the sludge settling quality. Figure 5 illustrates that from the start up of the acclimation to 60\% OMW mass ratio feeding the bioreactor, it was noticed that the SVI had not varied too much and the values measured were maintained at around $120 \mathrm{~mL} / \mathrm{g}$, indicating healthy sludge settling. Even if the SVI was good, the removal of COD revealed several slight drops $(10 \%)$ while increasing OMW ratio had revealed unstable water clarification over time. The disturbance of biomass activity had directly affected the sludge settling quality contrary to MBR. The coupled membrane with this reactor played a physical barrier to biomass disaggregation in stress periods which did not affect the water clarification quality. From $60 \%$ to $90 \%$ OMW mass ratio used for the CAS treatment, the SVI decreased slightly to $97 \mathrm{~mL} / \mathrm{g}$ but still indicated good sludge settling ability. The measured value remained comparable to values obtained by Diez et al. (2002) $(55-112 \mathrm{~mL} / \mathrm{g})$ who treated bleached kraft paper using an activated sludge system.

At stable state in the MBR, the membrane filtration was effective and the fouling was easily managed due to favorable hydraulic conditions of external ceramic MBR. Furthermore, the treatment in the MBR was effective.

The use of MF had a great potential for water clarification resulting in a highly clear effluent reaching a rate of MLSS elimination lower than $5 \mathrm{mg} / \mathrm{L}$ and a turbidity removal of $98 \%$. In the case of CAS, the SVI increased noticeably and was maintained around $136-150 \mathrm{~mL} / \mathrm{g}$. According to Shahzad et al. (20I5) the obtained values of SVI still reveal an acceptable biomass settling; however, the values above $150 \mathrm{~mL} / \mathrm{g}$ demonstrate poor settling ability. For the CAS performance, the removal of MLSS reached a rate of $88 \%$ with MLSS concentration in the outlet of $30 \mathrm{mg} / \mathrm{L}$. The results showed clearly that the MBR was capable of providing an effluent with a better quality than CAS.

Composition of SMP and properties. Figure 6 presents the evolution of proteins, polysaccharides and humic substances concentrations over time in MBR and CAS pilots. Proteins, polysaccharides and humic substances are quantified as the main SMP components.

During the acclimation period for the MBR, the results showed an increase of SMP concentration (i.e. proteins and polysaccharides) in the bioreactor simultaneously with the introduction of new OMW doses (at day 31 and from day 38 to day 45 and at day 53). In the case of CAS, the SMP increase (i.e. proteins) in the bioreactor was visible over time with the two relatively high OMW concentrations applied (at days 13 and 27). This surge of SMP is likely due to the high response of the microorganisms to the effluent augmentation in order to assure their selfdefense and protection against the toxic conditions of the environment they existed in. However, in MBR, the membrane fouling propensity increased as these SMP were produced. The UF membrane $(150 \mathrm{kDa})$ retained a part of SMP and OMW components, promoted their deposition greatly on its surface. In CAS, the production of SMP has not affected badly the quality of sludge flocculation and its settling ability. Proteins are the main fraction of the SMP produced. The presence of this fraction participates in the formation of strong bonds between biomass cells resulting in good flocs flocculation and the occurrence of a healthy water clarification (Avella Vasquez 20I0). The low presence of these substances in the settling tank $(4 \mathrm{mg} / \mathrm{L})$ compared to supernatant bioreactor $(13 \mathrm{mg} / \mathrm{L})$ confirmed their active implication in the flocs formation and robustness. Afterwards, at steady state in the MBR the concentration of SMP fractions was stable at a low level. The SMP proteins and polysaccharides were retained effectively by MF at $74 \%$ and $92 \%$, respectively, while in the case of applying UF membrane, the retention of these components was around $50 \%$ and $65 \%$. In regard to MBR set up, Villain-Gambier et al. (2019) obtained similar results and showed in their experience that SMP retention rate highly decreased under stressful conditions compared to the normal conditions applied. These authors noticed that under stressful conditions consisting of the decrease of F/M ratio, a drop of the biomass of $11 \%$ was observed and an increase of SMP production. This SMP was mainly composed of proteins fraction with low molecular weight components of 400,200 and $20 \mathrm{kDa}$ and which has contributed drastically to the membrane fouling. The membrane was regularly fouled during acclimation step (four times) requiring the process to stop and chemical cleaning whereas fouling was more progressive at a stable state. It seems that during the first period with UF membrane, a higher amount of SMP compounds were produced and participated in the membrane fouling. For the CAS treatment, at a stable state the amount of SMP substances was the same in the bioreactor supernatant and settling tank except for the SMP proteins where their amount was slightly lower in the settling tank $(2 \mathrm{mg} / \mathrm{L})$ than in the bioreactor supernatant $(4 \mathrm{mg} / \mathrm{L})$. 

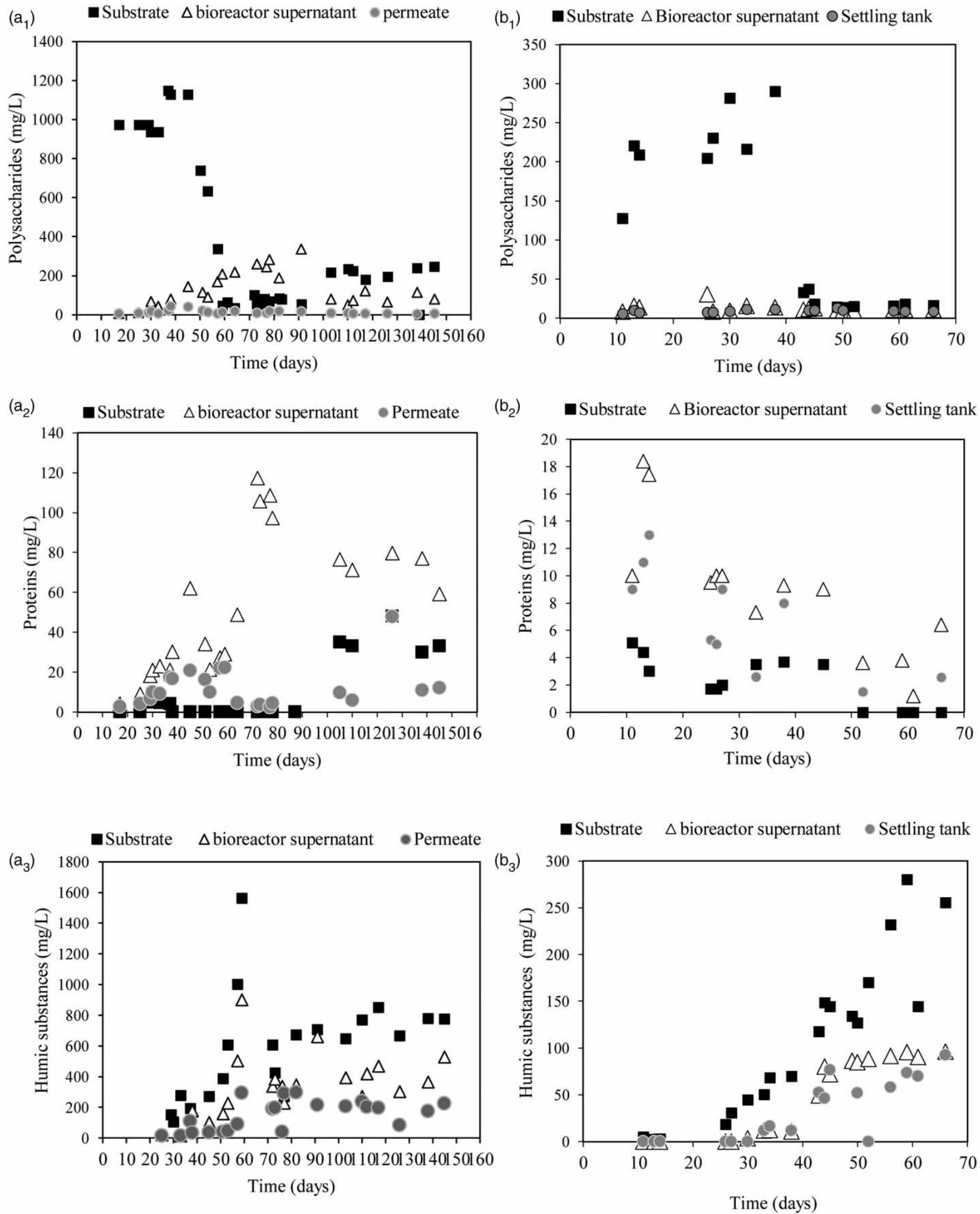

Figure 6 | Evolution of SMP production during time in MBR and CAS pilots: polysaccharides $\left(a_{1}, b_{1}\right)$ proteins $\left(a_{2}, b_{2}\right)$ and humic substances $\left(a_{3}, b_{3}\right)$. 
Figure 7 illustrates the SMP concentrations at a stable state in CAS and MBR pilots. The results revealed that a great part of SMP substances noted inside both bioreactors came from the influents used. Nevertheless, the influent feeding the MBR contained higher SMP concentrations compared to the effluent feeding CAS. This shows obviously that SMP production in both bioreactors was not all related to biomass release but it came from OMW influents. Moreover, the content of humic substances and polysaccharides knew a higher decrease in the biological reactors of CAS and MBR compared to their initial content in OMW influents. This decrease could be the result of various phenomenon such as their sorption on bioflocs, their participation to bound EPS or their elimination by sludge waste (Villain et al. 2014).

Strategy of OMW treatment in Morocco. Morocco is one of the Mediterranean countries concerned with a massive production of olive oil, with an annual production capacity of 2 million tons of olives and is the fourth largest producer of olives according to the agriculture ministry report of 2018.

In Marrakesh-Safi region, the olive oil industry produced about 305,000 tons per year of olives and a quantity of oil of 40,000 tons per year. In addition, the annual volume of OMW produced in this region is estimated at $152,500 \mathrm{~m}^{3} /$ year.

Several valorization methods have been suggested for OMW including bioconversion of oil mill wastes to bio-energy and biomolecules production, OMW field spreading and OMW application as biopesticides. The other option consisted of OMW biodegradation, using aerobic technologies. At large scale, the activated sludge process remains the most practical way for wastewater treatment. Nevertheless, the complex composition of OMW and its high level of toxicity hinders the success of such a method for OMW biodegradation. Therefore, there is a mandatory requirement for inventing new strategies that could find a real world experience, aimed at both reducing water pollution and its reuse.

Recently, Jaouad et al. (2016) showed in their research that for an optimal biodegradation of OMW, a dilution of OMW with water until $2 \mathrm{gCOD} / \mathrm{L}$ must be achieved. This means that a high amount of water is needed for the best OMW treatment; however, due to its serious cost implication and its low adaptation to countries facing drought problems, this dilution approach remains inefficient. For a practical application of OMW treatment in CAS or MBR, the idea suggested in this study aimed to dilute OMW with domestic wastewater that feeds WWTP instead of water, which could be more economic and more affordable. It essentially consists of mixing this effluent at a gradual mass ratio with domestic wastewater to ensure the biomass acclimation as performed in the present study. A good OMW treatment will be attained according to the results found in a laboratory CAS pilot treating it. The COD of the treated water $(152 \mathrm{mg} / \mathrm{L})$ is slightly higher than the given value by Moroccan Standard for Wastewater Discharge $(120 \mathrm{mg} / \mathrm{L})$. However, the MLSS concentration $(30 \mathrm{mg} / \mathrm{L})$ complies with MLSS standard limits. The second purpose of the strategy is the treatment of OMW in MBR WWTP. The alimentation of MBR is planned to be the same as the CAS WWTP. According to the results reporting, the biodegradation of OMW in a laboratory MBR plant, the MBR will perform higher than CAS to

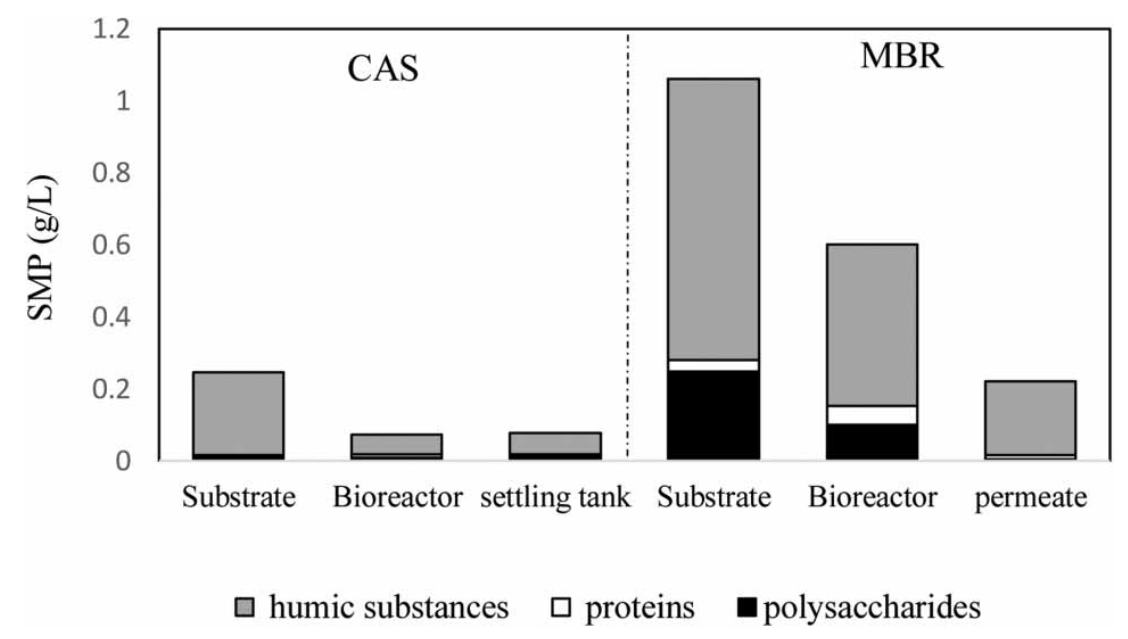

Figure 7 | SMP substances concentrations (proteins, polysaccharides and humic-like substances) at stable state in CAS and MBR pilots. 
treat OMW and thus, giving a treated water respecting largely the Moroccan standards. The removal of COD $(107 \mathrm{mg} / \mathrm{L})$ and MLSS $(5 \mathrm{mg} / \mathrm{L})$ are significantly lower than the standard values. Even though the removal efficiency of CAS was slightly lower than the MBR, this last seems to be sufficient for OMW treatment regarding the Moroccan context and the legal environment requirements for wastewater discharge. The use of the MBR instead of CAS could be positive from one side, notably because it is delivering water with a good quality, it is flexible and it requires a small footprint. However, considering the economic-financial side, the MBR is both an expensive and high energy-consuming system. Several studies pointed out the cost as a major drawback for MBRs' widespread implementation. For instance, according to the study performed by Kamble et al. (2019) using life cycle cost (LCC) approach, they revealed that the capital cost of MBR (24.8 million/millions of L per day (MLD)) was extremely higher than CAS (6.9 million/MLD). Moreover, this study showed that the MBR is a higher energyconsuming process (1.69 MégaJoules $/ \mathrm{m}^{3}$ ) compared to CAS $\left(0.682\right.$ MégaJoules $\left./ \mathrm{m}^{3}\right)$. Using the same evaluation approach (LCC), Bertanza et al. (2017) demonstrated that the cost of MBR being $12-18 € /$ p.e/y greater than that of the CAS and, at the same time, it consumes more energy (73 kWh/p.e/y) than CAS (52 kWh/p.e/y).

In Morocco, the activated sludge wastewater treatment plants are implemented in most large cities and locally adapted for the treatment of domestic wastewater. Furthermore, this study revealed that this technology could be fairly applicable and effective for OMW treatment. Then, why is it necessary to seek for another alternative technology like MBR if just the fees of the MBR set up and operation would increase for approximately the same performance deliverance for both plants? Therefore, for the Morrocan context the suitable choice goes to CAS rather than MBR.

From another side, nowadays there is a need of appropriate technologies for water reuse to fight problems of water scarcity and limited rainfall facing Moroccan regions. Several studies showed that CAS through the secondary treatment could produce a good-quality effluent with the removal of the most unwanted elements but still for CAS a tertiary disinfection step is required to ensure microbial quality and to avoid sanitary risks. Disinfection following MBR treatment may not be needed as the latter can provide, on its own, a better removal of microorganisms. Moreover, as noted in the study by Francy et al. (2012), the MBR could be more effective in post-disinfection than UV or chlorine disinfectants, which are the most used in CAS. In this case, the MBR can be proposed as an alternative in post disinfection after the wastewater secondary treatment and as an alternative to the other disinfectants, which are also too expensive, involving high charges for their application and having numerous side effects for the treatment.

\section{CONCLUSION}

In this study, the performance of an external ceramic MBR and CAS plants treating OMW was evaluated. In the first step, an acclimation procedure was used in both reactors to ensure the preadaptation of the microorganisms to OMW biodegradation. For that, a progressive increase of OMW content was applied against an easily biodegradable substrate over time. After the acclimation step, the pilots were fed with $\mathrm{OMW}$ at $2 \mathrm{~g} \mathrm{COD} / \mathrm{L}$ respecting rates of $0.2 \mathrm{~kg}_{\mathrm{COD}} / \mathrm{kg}_{\mathrm{MLVsS}} / \mathrm{d}$ of organic loading and $8 \mathrm{~g} / \mathrm{L}$ of MLVSS for MBR and rates of 0.3 of organic loading and $5 \mathrm{~g} / \mathrm{L}$ of MLVSS for CAS. Biomass acclimation was then successfully obtained in both pilots. However, the MBR showed a better adaptation to operational condition fluctuations than CAS; that was confirmed by both higher and constant COD removal achievement (95\%). At a stable state, MBR performed better than CAS. A higher rate of COD removal was attained (95\%) for MBR against 86\% for CAS pilot. Moreover, permeate of MBR was free from MLSS whereas CAS treated water contained $30 \mathrm{mg} / \mathrm{L}$ of MLSS. In addition to that, the fouling was easily managed in MBR and a quite effective water clarification was noticed for CAS. Consequently, CAS was suitable for OMW treatment and MBR could be suggested as an alternative to CAS when a better effluent quality has to be guaranteed.

\section{REFERENCES}

Avella Vasquez, A. C. 2010 Substances polymériques extracellulaires dans les procédés de traitement des eaux usées (Extracellular Polymeric Substances in Wastewater Treatment Processes). PhD Thesis, National Polytechnic Institute of Lorraine, Vandœuvre-lès-Nancy, France.

Baresel, C., Harding, M. \& Fang, J. 2019 Ultrafiltration/granulated active carbon-biofilter: efficient removal of a broad range of micropollutants. Applied Sciences 9, 1-12. doi: 10.3390/ app9040710.

Baransi, K., Dubowski, Y. I. \& Sabbah, I. 2012 Synergetic effect between photocatalytic degradation and adsorption processes on the removal of phenolic compounds from olive mill wastewater. Water Research 46 (2012), 789-798. 
Bertanza, G., Canatoa, M., Laerab, G., Vaccaria, M., Svanströmc, M. \& Heimerssonc, S. 2017 A comparative techno-economicenvironmental assessment of full-scale CAS vs MBR technologies. Environmental Science and Pollution Research 24 (21), 17383-17393.

Dhaouadi, H. \& Marrot, B. 2008 Olive mill wastewater treatment in a membrane bioreactor: process feasibility and performances. Chemical Engineering Journal 145, 225-231.

Diez, M. C., Castillo, G., Aguilar, L., Vidal, G. \& Mora, M. L. 2002 Operational factors and nutrient effects on activated sludge treatment of Pinus radiata kraft mill wastewater. Bioresource Technology 83 (2), 131-138.

DuBois, M., Gilles, K. A., Hamilton, J. K., Rebers, P. A. \& Smith, F. I956 Colorimetric method for determination of sugars and related substances. Analytical Chemistry 28 (3), 350-356.

Ergüder, T. H., Güven, E. \& Demirer, G. N. 2000 Anaerobic treatment of olive mill wastes in batch reactors. Process Biochemistry 36, 243-248.

Esmail, A., Chahboun, N., Mennane, Z., Amiyare, R., Abed, H., Barrahi, M., Qebibo, A., Ouhssine, M. \& Berny, E. H. 2015 Study of antimicrobial activity of olive mille wastewater (OMWW) from Fez Boulman against some pathogenic strains. Journal of Materials and Environmental Sciences 6 (3), 869-876.

Farabegoli, G., Chiavola, A. \& Rolle, E. 20I2 SBR treatment of olive mill wastewaters: dilution or pre-treatment? Water Science \& Technolgy 56 (9), 1684-1691.

Fazal, S., Zhang, B., Zhong, Z., Gao, L. \& Chen, X. 2015 Industrial wastewater treatment by using MBR (membrane bioreactor) review study. Journal of Environmental Protection 6 (6), 584-598.

Francy, D. S., Stelzer, E. A., Bushon, R. N., Brady, A. M. G., Williston, A. G., Riddell, K. R., Borchardt, M. A., Spencer, S. K. \& Gellner, T. M. 2012 Comparative effectiveness of membrane bioreactors, conventional secondary treatment, and chlorine and UV disinfection to remove microorganisms from municipal wastewaters. Water Research 46 (13), 4146-4148.

Frolund, B., Griebe, T. \& Nielsen, P. H. 1995 Enzymatic activity in the activated-sludge floc matrix. Applied Microbiolgy Biotechnology 43, 755-761.

Gizgis, N., Georgiou, M. \& Diamadopoulos, E. 2006 Sequential anaerobic/aerobic biological treatment of olive mill wastewater and municipal wastewater. Journal of Chemical Technology and Biotechnology 81 (9), 1563-1569.

Jaouad, Y., Villain, M., Ouazzani, N., Mandi, L. \& Marrot, B. 2016 Biodegradation of olive mill wastewater in a membrane bioreactor : acclimation of the biomass and constraints. Desalination and Water Treatment 57 (18), 8109-8118.
Jaouad, Y., Villain-Gambier, M., Mandi, L., Marrot, B. \& Ouazzani, N. 2018 Key process parameters involved in the treatment of olive mill wastewater by membrane bioreactor. Environmental Technology 40 (24), 3162-3175.

Kamble, S., Singh, A., Kazmi, A. \& Starkl, M. 2019 Environmental and economic performance evaluation of municipal wastewater treatment plants in India: a life cycle approach. Water Science \& Technology 79 (6), 1102-1112.

Moroccan Standards for Wastewater Discharge 2013 Moroccan Ministry of Energy, Mines, Water and Environment. Protection of Water Resources and Fight Against Pollution, Morocco.

Paraskeva, P. \& Diamadopoulos, E. 2006 Technologies for olive mill wastewater (OMW) treatment: a review. Journal of Chemical Technology and Biotechnology 81 (9), 1475-1485.

Rahmani, M. 20Io La qualité: Facteur compétitif pour la promotion de la filière et indispensable pour le respect de l'environnement (Quality: Competitive factor for the promotion of the sector and essential for the respect of the environment), Day of the AMIOL association on the theme: The olive tree: Quality - Health-Environment.

Shahzad, M., Khan, S. J. \& Paul, P. 20I5 Influence of temperature on the performance of a full-scale activated sludge process operated at varying solids retention times whilst treating municipal sewage. Water 7 (3), 855-867.

Sipma, J. B., Osuna, B., Collado, N., Monclús, H., Ferrero, G., Comas, J. \& Rodriguez-Roda, I. 20Io Comparison of removal of pharmaceuticals in MBR and activated sludge systems. Desalination 250 (2), 653-659.

Stoller, M., Azizovab, G., Mammadovac, A., Vilardia, G., Di Palmaa, L. \& Chianesea, A. 2016 Treatment of olive oil processing wastewater by ultrafiltration, nanofiltration, reverse osmosis and biofiltration. Chemical Engineering Transactions 47, 409-414.

Villain, M., Bourven, I., Guibaud, G. \& Benoit, M. 2014 Impact of synthetic or real urban wastewater on membrane bioreactor (MBR) performances and membrane fouling under stable conditions. Bioresource Technology 155, 235-244.

Villain-Gambier, M., Bourven, I., Guibaud, G. \& Marrot, B. 2019 Influence of proteins and humic-like substances from soluble microbial products on membrane bioreactor fouling under normal and stress conditions. Process Biochemistry 78, 140-147.

Yahiaoui, O., Lounici, H., Abdi, N., Drouich, N., Ghaffour, N., Pauss, A. \& Mameri, N. 20II Treatment of olive mill wastewater by the combination of ultrafiltration and bipolar electrochemical reactor processes. Chemical Engineering and Processing: Process Intensification 50 (1), 37-41. 